\title{
LIDSKÝ KAPITÁL JAKO JEDEN Z KLÍČOVÝCH ROZVOJOVÝCH FAKTORŮ
}

\section{HUMAN CAPITAL AS A ONE OF THE KEY DEVELOPMENT}

FACTOR

\author{
PhDr. Dana hÜBELOVÁ, Ph.D. \\ Ústav demografie a aplikované statistiky $\mid$ Department of Demography and Applied statistics \\ Fakulta regionálního rozvoje a mezinárodních studii Faculty od Reg. Development and Intern. Studies \\ Mendelova univerzita $v$ Brně Mendel University \\ $\triangle$ Trida Generala Piky 2005/7, 61300 Brno, Czech Republic \\ E-mail: hubelova@mendelu.cz
}

\begin{abstract}
Anotace
$V$ druhé polovině 20. století se začinaji formovat nové typy kapitálu, mezi nimiž hraje významnou roli také lidský kapitál. Lidský kapitál představuje znalosti, dovednosti, schopnosti a vlastnosti jedince, které usnadňuji vytváření osobního, sociálního a ekonomického blaha a stávaji se stále di̊ležitějšimi pro prosperitu celé postindustriální společnosti. Př́spěvek tuto skutečnost dokazuje na príkladech vyspělých zemi světa. Současně dokládá, že velmi významnou součástí lidského kapitálu je vzdělávání, které disponuje tou výhodou, že je měritelné. Díky tomu je možné sledovat tendence vývoje vzdělávání $v$ České republice a př́činy a di̊sledky vývojového trendu.
\end{abstract}

\section{Klíčová slova}

lidský kapitál, vzdělávání, postindustriální společnost

\section{Annotation}

New types of capital began to emerge in the second half of 20th century. The new capital has also become human resources, which are increasingly important. Human capital is the knowledge, skills, abilities and individual qualities that help create a personal, social and economic well-being, which is important for the prosperity of the post-industrial society. In the contribution it is shown on example of developed countries. There is also analyzes significant part of the human capital-education, which has the advantage that it is measurable. Thus we can follow up trends in education in the Czech Republic and the causes and consequences of the trend.

Key words

human resources, education, post-industrial society

JEL classification: 125

\section{Úvod}

V současnosti je pro vyspělé země typická dynamicky se rozvíjející informační a znalostní společnost. V těchto zemích dochází (nebo už došlo) k pomalému vyčerpání tradičních surovinových zdrojů, které mohou být (nebo byly) hlavním hnacím prvkem hospodářského růstu investice do lidského kapitálu, rozvoje vzdělanosti, lidských zdrojů, technologií a vědy. Prezentovaný text zdůrazňuje pochopení důležitosti rozvoje lidského kapitálu, který může urychlit a výrazně přispět $\mathrm{k}$ prosperitě na makroekonomické, i mikroekonomické úrovni. Vyšší úroveň lidského kapitálu přináší výhody jak jednotlivcům, tak i celé společnosti nebo jednotlivým zemím. 
Obsahovou náplň př́spěvku je možné rozdělit dle dvou obecných cílů. Prvním cílem na úrovni teoretické je objasnit a definovat pojem lidský kapitál a lidské zdroje, nebot' v české literatuře není dané problematice věnováno tolik pozornosti jako v zahraniční. Druhý cíl se pokouší na úrovni praktické, a to pomocí analýzy vybraných socio-demografických ukazatelů, specifikovat současnou situaci z pohledu zdrojů a investic do lidského kapitálu v České republice. Zaměřuje se podrobněji na vybrané charakteristiky vzdělávání, které je jedním z významných složek intelektuálního kapitálu.

\section{Kapitál jako ekonomický pojem}

Již známý britský ekonom první poloviny 19. století N. W. Senior nazval kapitál „zbožím, které není spotřebováváno, nýbrž je dále používáno ve výrobě. A práce vybavená tímto zbožím je produktivnější. Jinak řečeno, kapitál je produktivní.“ (citováno dle Holman, 2005, s. 78). Kapitál je tedy schopen svého zhodnocení. Alternativně je možné definovat pojem kapitál jako finanční aktiva, která mohou být investována na primárním kapitálovém trhu. Druhá možnost pouze nahlíží na kapitál z hlediska finančního vyjádření, v jádru jsou však obě shodné. Kapitál se vyznačuje několika důležitými znaky, které jsou základem pro jeho pojetí v ekonomii, a je v první radě jistou formou investice.

\section{Nové typy kapitálů}

V průběhu druhé poloviny 20. století se začíná postupně ve vědeckých pracích vymezovat hned několik druhů kapitálu. Veselý $(2006$, s. 8) k tomuto problému uvádí, že rozvětvená typologie kapitálů je užívána především v oblasti rozvojových studií, trvale udržitelného rozvoje, nejrůznějších strategických a koncepčních dokumentech. Z hlediska metodologie je však problémem objektivní vymezení nových typů kapitálů. Typologie kapitálů nejsou opřeny o žádný sjednocující teoretický rámec, který by zaručoval, aby jednotlivé typy kapitálu skutečně ve svém úhrnu zahrnovaly všechny dostupné zdroje a současně aby nedocházelo k jejich vzájemnému nepřekrývání. Mnohé kapitály (zejména pak kapitály sociální a kulturní) jsou velmi nejasně definovány a jejich užití je do značné míry intuitivní. Velký problém pak vykazují typologie s vymezením vědění, znalostí, dovedností, které jdou např́ic různými kapitály. Podle Veselého (2006, s. 9) můžeme rozlišovat následující formy kapitálů:

- přírodní,

- fyzický,

- finanční,

- sociální,

- kulturní,

- lidský kapitál.

Přírodním kapitálem se rozumí prrírodní zdroje, jako je půda, lesy, minerály, ovzduší atd. Fyzický kapitál jsou materiální výrobní prostředky vytvořené lidmi (stroje a zařízení atd.), určené pro výrobu statku a služeb. Finančním kapitálem jsou myšleny dostupné finanční prostředky, jako jsou úspory, akcie a dluhopisy. Sociální kapitál je chápán jako společenské sítě mezi lidmi a vzájemnou důvěra a porozumění mezi nimi. Kulturní kapitál jsou materiální produkty, které nelze bezprostředně využít pro výrobu komodit a služeb. Kulturní kapitál nabývá dvou forem. Explicitní kulturní kapitál zahrnuje materiální objekty, jejichž primárním účelem je uchovávat, předávat či zpracovávat vedení (knihy, noviny, $\mathrm{CD}$, počítačový software, databáze atd.). Oproti tomu implicitním kulturním kapitálem jsou v podstatě všechny člověkem vytvořené produkty (kulturní, ale také spotřební předměty), kde vědění je vtěleno př́mo do výrobku, a nelze ho jednoduše kopírovat a komunikovat dále (bez toho, že by byl okopírován celý materiální objekt).

Lidský kapitál je vědění vtělené v lidech. Lze jej rozdělit na znalosti (tj. poznatky a informace, které jedinec má a které je schopen nějakým způsobem vyjádřit a komunikovat) a poznávací i výkonové dovednosti, které jsou aktuálními schopnostmi konkrétního člověka, a jako takové bezprostředně nepřenositelné (srov. Veselý, 2006, s. 9). 


\section{Lidský kapitál}

Lidský kapitál je termín, který je starý jen několik málo desetiletí. Nejedná se zatím o zcela přesně definovaný a ustálený pojem a různí autoři interpretují lidský kapitál rozličně. Obecně je možné lidský kapitál vymezit jako znalosti a dovednosti, kterými jedinec disponuje. Lidským kapitálem můžeme rozumět i produktivní schopnosti člověka, tedy to, co je investováno do produkce. Takto chápaný lidský kapitál je označován jako základní lidský kapitál. Jeho rozšiřením pak vzniká tzv. širší lidský kapitál, kterým se rozumí potenciál rozvíjet a uplatňovat své schopnosti.

Zakladatel teorie lidského kapitálu Gerry Becker, definoval lidský kapitál jako schopnosti, dovednosti a odpovídající motivace tyto schopnosti a dovednosti uplatnit. Rovněž uvádí, že se jednotlivci rozhodují o účasti na tvorbě lidského kapitálu jako o investici na základě porovnání výnosů a nákladů. V jeho pojetí jsou výnosy např. vyšší mzdy, lepší zaměstnání, ale třeba i nepeněžní výnosy jako zlepšení zdraví, kulturní vzdělanost, posun na společenském žebř́̌čcu. Nákladem je hodnota času (náklady ztracené př́iležitosti) a hodnota výdajů na pořízení těchto investic. Současně přikládá velký význam v rámci lidského kapitálu znalostem a zdraví (srov. Becker, 1993).

Podle dokumentu Národního vzdělávacího fondu České republiky je lidský kapitál definován jako zásoby znalostí a dovedností ztělesněných $\mathrm{v}$ pracovní síle, jež jsou výsledkem vzdělání a praxe a pracovní sílu zhodnocují (Konkurenční schopnost České republiky - kvalita lidských zdrojů, 2012). Podobnou definici vypracovala OECD, podle níž lidský kapitál představují znalosti, dovednosti, schopnosti a vlastnosti jedince, které usnadňují vytváření osobního, sociálního a ekonomického blaha.

Lidské zdroje - lidský kapitál je jednou ze složek intelektuálního kapitálu, který určuje kvalitativní úroveň noosféry prostorové jednotky. Lidským kapitálem v užším pojetí můžeme rozumět jako:

- souboru znalostí, fyzických a intelektuálních,

- osvojeným komunikačním schopnostem,

- nezbytným manuálním a praktickým dovednostem,

- cíleně vytvářené motivaci.

Lidský kapitál však není jen výsledkem vzdělávání, ale podílí se na něm celá řada složek a faktorů, které se utvářejí v průběhu života každého jedince a mezi které můžeme řadit:

- vzdělávání,

- vrozené schopnosti,

- rodinné prostředí,

- sociální prostředí.

Pokud tedy budeme chtít lidský kapitál měřit, měli bychom vzít v úvahu všechny tyto vlivy. Jenomže ohodnotit vrozené schopnosti a rodinné a sociální prostředí neumíme, tak si pomáháme předpokladem, že lidský kapitál je především výsledkem vzdělávání. Měřit bychom měli to, co se do jedince vloží, tedy objem znalostí a dovedností. Jenomže to také neumíme, takže jako náhražku, jako přibližnou míru, můžeme používat délku vzdělávání (Koschin, 2005). Je patrné, že výše jmenované složky lidského kapitálu jsou získávány zejména $\mathrm{v}$ procesu vzdělávání a osvojování praktické činnosti člověka, se zaměřením na tvorbu schopností použitelných pro:

- vytvoření nové hodnoty,

- uspokojení společenské potřeby

- uspokojení osobní potřeby

- zvýšení některé z forem regionálního kapitálu.

Jedná o potenciál skrytý $\mathrm{v}$ hlavách lidí, který nemusí být nijak zachycen, ale pro společenský a ekonomický rozvoj země je navýsost žádoucí umět tento potenciál vytvářet, sdílet a využívat.

Ekonomové mívají problémy s vysvětlením, proč některé státy v historii zaznamenaly dlouhá období stálého růstu př́ijmů na osobu. Př́ijem na osobu zpravidla roste jako důsledek obdělávání nových ploch půdy a produkce fyzického kapitálu na jednoho zaměstnance. Tento růst však dříve či později 
eliminují klesající výnosy z rozsahu, kdy není těžké vysvětlit zpomalování nebo stagnaci, ale obtížněji se vysvětluje, proč ekonomiky rostou, když př́rodní zdroje jsou již téměř vyčerpány (viz vývoj v USA, v Japonsku a ve vyspělých zemích Evropy).

Odpověd' je nutné hledat ve vývoji vědy a technických znalostí, které zvyšují produktivitu práce. Aplikací vědeckých poznatků ve výrobě se zvýšil význam vzdělání ${ }^{4}$, výcviku technických dovedností a výcviku na pracovním místě. Hypotézu, že rozvoj vzdělanosti a investice do lidského kapitálu jsou přičinou dlouhodobého ekonomického růstu, podporuje např́ílad vývoj v Japonsku nebo $\mathrm{v}$ dalších asijských zemích, které trpí nedostatkem př́rodních zdrojů. Přesto zásluhou investic do lidského kapitálu, díky dobře trénovaným, vzdělaným a tvrdě pracujícím zaměstnancům, dosahují dobré hospodářské úrovně. Další důkaz o závislosti ekonomického růstu na lidském kapitálu, je možné vysledovat $\mathrm{v}$ charakteru dnešního zemědělství. $\mathrm{V}$ tradičních zemědělských společnostech vzdělání nebylo důležité a nezbytné znalosti předávali svým dětem rodiče, rolníci po staletí patřili mezi vrstvy s nejnižším vzděláním. Dnešní farmáři však musejí umět zacházet $\mathrm{s}$ výpěstky, musejí zvládnout nové šlechtitelské a chovatelské metody, nové metody oplodňování, musejí se naučit zacházet s citlivými a složitými př́stroji atd. Vzdělání je tak dnes hlavním prostředkem k zachování konkurenceschopnosti i $\mathrm{v}$ zemědělství.

\section{Lidský kapitál a Česká republika}

Můžeme tedy na základě výše uvedeného vycházet $\mathrm{z}$ faktu, že stroje a výrobní technologie lze sice převést do různých zemí, ale jádro původních zaměstnanců je vázáno $\mathrm{k}$ místu výroby $\mathrm{v}$ daném regionu. V České republice - exportně orientované zemi a převážně odkázané na dovoz hlavních energetických surovin - je možné považovat za nejvýznamnější rozvojový faktor v nastupující postindustriální epoše právě lidské zdroje a lidský kapitál.

V České republice vláda vynakládá na vzdělávání $4,8 \%$ HDP, zatímco země OECD vydají v průměru na vzdělání veřejné a soukromé finanční prostředky ve výši $6,2 \%$. Průměr zemí EU přesahuje $6 \%$ HDP a podle tohoto kritéria patří naše republika mezi sedm nejhorších zemí EU. Výdaje Ministerstva školství, mládeže a tělovýchovy ČR na regionální školství (mateřské školy, základní a stř̌ední školy) mají dvě složky:

- mzdové náklady učitelů,

- provozní náklady škol, což jsou tzv. ostatní neinvestiční výdaje, kde výraz „ostatní“ zahrnuje vše ostatní mimo mzdy.

Ostatní neinvestiční výdaje, ze kterých hradí školy vše, co je potřebné pro výuku (počínaje náklady na úklid či na základní škole pronájem bazénu pro výuku plavání, nezbytné učebnice a další pomůcky), byly od roku 2007 snižovány z hodnoty 1,6 mld. Kč na hodnotu pouhých 400 tisíc Kč v roce 2012. Je to snížení přibližně o tři čtvrtiny. Protože však v průběhu pětiletého období se zvýšila daň z přidané hodnoty (DPH), kterou školy při nákupech vrací státu z $5 \%$ na $14 \%$, celkový pokles představuje zhruba $80 \%$. Př̀es uvedené snížení nákladů ve školství máme v České republice v rámci Evropské unie nejméně lidí bez ukončeného základního vzdělání (evidováno je jen osm procent osob bez základního vzdělání, přičemž průměr EU činí $26 \%$ ). Středoškolským vzděláním disponuje $75 \%$ Čechů, což zemi řadí na první příčky, i když ve školním roce 2011/12 nezvládlo maturitu 18,6 \% středoškoláků.

Propad však nastává $\mathrm{v}$ oblasti univerzitního studia. V Evropské unii činí průměrný podíl vysokoškoláků v populaci zhruba $24 \%$, ale v České republice se absolutoriem vysoké školy, včetně bakalářského studia, může chlubit jen zhruba šestina populace, což řadí Českou republiku v rámci Evropské unie na sedmé místo odspodu. Pozitivní je jistě růst počtu vysokoškoláků (srov. tab. 1), nebot' v roce 2000 přijímaly školy jen $25 \%$ přihlášených, nyní už je to přibližně $60 \%$ uchazečů (v některých letech se jednalo dokonce až o 90 \% osob daného generačního ročníku).

\footnotetext{
${ }^{4} \mathrm{~V}$ minulém století se základní školní vzdělání stalo celosvětovým standardem a jako nový standard se rozšiřuje střední vzdělání s maturitou. Děti ze středních tříd a z „chudých“ rodin navštěvují vysoké školy.
} 
Tab. 1: Srovnání počtu vysokoškoláku podle Sčitání lidu, domů a bytů

\begin{tabular}{|l|c|c|c|}
\cline { 2 - 4 } \multicolumn{1}{c|}{} & \multicolumn{3}{|c|}{ Rok sčítání a absolventi (relativně v \%) } \\
\cline { 2 - 4 } & 1991 & 2001 & 2011 \\
\hline Dokončené vysokoškolské vzdělání & 7,2 & 8,9 & 10,1 \\
\hline
\end{tabular}

Uvedený růst však nese také některé problematické otázky, ke kterým můžeme zařadit:

- Růst počtu studentů na našich vysokých školách je ve světě výjimečný, na druhé straně je otázkou, zda tak velký podíl populace má vůbec intelektuální schopnost absolvovat opravdu náročné vysokoškolské studium.

- Nárůst počtu studentů je př́činou „masifikace vysokoškolského studia“. Diskutabilní v této souvislosti není jen možnost udržení odpovídající a mezinárodně srovnatelné kvalitativní úroveň více než 70 českých vysokých škol s několika tisíci studijních oborů, ale také finanční udržitelnost takového počtu.

- Požadavky na mezinárodně srovnatelnou vysokou kvalitu lidských zdrojů potřebných $\mathrm{v}$ postindustriální společnosti jsou do jisté míry v rozporu s masovostí vysokoškolského studia.

- Za závažnou je možné považovat skutečnost, že v České republice $13 \%$ mladých lidí ve věku od 15 do 29 ani nestuduje a ani nepracuje.

- Varující je stálý pokles počtu vysokoškolsky vzdělaných osob v oborech přírodních a především technických věd. V roce 2000 mělo v těchto dvou oborech diplom celkem $36 \%$ všech vysokoškoláků. Nyní se hodnota již blíži $30 \%$, přičemž přes $80 \%$ z těchto vysokoškolských odborníků jsou muži. V postindustriální společnosti zajištují její rozvoj právě odborníci na techniku a přírodní vědy, kteří se angažují především ve vědě a inovacích.

- Počty absolventi̊ doktorských studijních programů neodpovídají počtu osob s ukončeným vysokoškolským studiem.

V rámci vysokoškolského vzdělávání neprobíhá žádná větší srovnávací analýza kvalitativní úrovně, proto můžeme porovnávat ve většině př́ípadů pouze počty studujících nebo absolventů či délku studia. Odlišná situace je tomu ale $\mathrm{v}$ rámci školství základního a středního, jehož úroveň je předpokladem zajištění budoucích kvalitních studentů na vysokých školách.

V této oblasti školního systému se jeví situace podle výsledků srovnávacích průzkumů PISA ${ }^{5}$ pro Českou republiku jako skutečně alarmující. V roce 2009 bylo realizováno šetření PISA již počtvrté (v letech 2000, 2003 a 2006 byla postupně věnována hlavní pozornost čtenářské, matematické a př́rodovědné gramotnosti). V roce 2009 se pozornost opět vrátila hlavně ke čtenářské gramotnosti tentokrát i se zřetelem $\mathrm{k}$ digitálním textům, která se zdá být $\mathrm{z}$ hlediska budoucího uplatnění člověka $\mathrm{v}$ životě nejdůležitější (což potvrzuje obdobný longitudinální průzkum realizovaný v Kanadě). Podle výsledků se vývoj průměrné úrovně čtenářské gramotnosti patnáctileté populace zemí OECD př́liš nemění, některé země se $\mathrm{v}$ průběhu tohoto období výrazně zlepšily, ale Česká republika patří $\mathrm{k}$ zemím, kde došlo k významnému zhoršení (obr. 1).

Podobný trend vykazuje vývoj průměrné úrovně matematické i prŕrodovědné gramotnosti, kde je Česká republika zemí, ve které došlo k největšímu propadu výsledkủ. Tím se naši studenti dostali pod průměr zemí $\mathrm{OECD}$, zatímco ještě $\mathrm{v}$ roce 2003 byli nadprůměrní jak v matematické tak i v prírodovědné gramotnosti.

\footnotetext{
${ }^{5} \mathrm{~V}$ rámci šetření PISA jsou zkoumány vědomosti a dovednosti, které jsou základem pro fungování člověka v moderní společnosti. Země, které se v roce 2009 zúčastnily tohoto šetření, reprezentují skoro 90 \% světové ekonomiky.
} 
Obr. 1: Vývoj průměrné úrovně čtenářské gramotnosti středoevropských zemí (počet bodi̊)

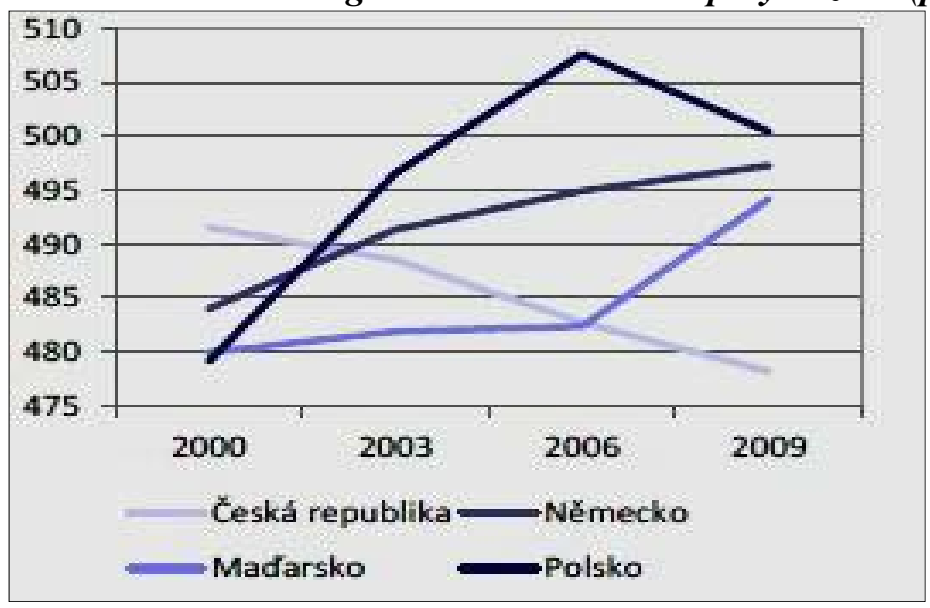

Zdroj: OECD, 2010

Uvedený propad kvality počátečního vzdělávání by mohl mít vážné důsledky nejen v odraze na dalším (napřr. vysokoškolském), ale i celoživotním vzdělávání. Ve spojení s ekonomickou depresí by v dlouhodobém výhledu mohla situace nepř́znivě dopadnout na rozvoj celé společnosti. Dnešní ekonomické turbulence je možné spojovat $\mathrm{s}$ tzv. formační krizí vázanou na dobíhání dlouhé deprese $\mathrm{v}$ rámci dlouhodobého Kondratjevova cyklu. Globální ekonomická krize zasáhla i Českou republiku, kde je úroveň národního hospodářství značně závislá na exportu, v němž se projevuje nízký stupeň disperze. Cyklický ekonomický pokles znamená recesi průmyslové výroby, snížení spotřeby obyvatelstva a pokles jeho životní úrovně. Pokles kupní síly nejpočetnější skupiny českého obyvatelstva se projevuje snížením nákladů věnovaných na rozvoj kvality lidských zdrojů a také snížením prostředků věnovaných na regeneraci a uvědomělé trávení volného času. Zpracovatelský průmysl v České republice tvoří více než $80 \%$ exportu a zaměstnává přes milion pracovníků. V hlavních exportních odvětvích pracuje přes 600 tisíc zaměstnanců. Přes polovinu českého exportu představuje vývoz strojů, včetně automobilů. Zhruba 83 \% vývozu jde do zemí Evropské unie, přičemž více než 30 \% jen do Německa. Po 10 \% směřuje do Polska, Rakouska a na Slovensko. Když tyto údaje sumarizujeme, zjistíme, že více než polovina našeho exportu je určena sousedním zemím.

Současná česká ekonomika je svojí úrovní cca 20 až 30 \% nad úrovní roku 1989. Levná pracovní síla a daňové úlevy nalákaly po roce 1989 do České republiky mnohé zahraniční výrobce, kteří sem však většinou lokalizovali pouze svoje jednoduché, převážně montážní výroby. Vyspělý svět opouští období industriální a přechází do postindustriálního období. Nové hodnoty vytváŕí kreativní výrobce silou intelektu. V České republice výše finančních prostředků vynakládaných státem na vzdělání zatím této skutečnosti plně neodpovídá.

\section{Závěr}

Přestože k tématu existuje poměrně rozsáhlá zahraniční literatura a odborné prameny, jeho zmocnění není tak snadné. V České republice nebylo doposud tomuto tématu věnováno tolik pozornosti jako v zahraničí a nedostatek kvalitních empirických studií tak zatím ponechává studium lidského kapitálu z velké části pouze $\mathrm{v}$ teoretické rovině.

Pro vývoj celé společnosti současnosti - nejen v České republice - je růst vzdělanosti populace jedním z klíčových faktorů. Vyspělé země světa se nacházejí ve fázi přechodu k postindustriální společnosti, ve které již není podstatná „práce svalư“, která byla nahrazena prací strojů, ale především „,práce mozkư", kreativita a schopnost adaptace jedince na změny společenské, ekonomické nebo sociální. Tato kreativita a adaptace jedince by bez dostatečného vzdělání (a vzdělávání) nebyla možná a je podstatná $\mathrm{k}$ úspěšnému rozvoji celé společnosti $\mathrm{v}$ budoucnosti. $Z$ tohoto důvodu je jistě pozitivním jevem rostoucí trend počtu studentů a absolventů vysokých škol, který se pravděpodobně udrží i v dalších letech. Uvedenou skutečnost potvrzuje i publikovaná prognóza lidského kapitálu (Koschin, 
2005, s. 51), v níž autor uvádí předpoklad, že poroste lidský kapitál, tedy vzdělanost obyvatelstva v České republice. Vzdělanost by měla růst nejen důsledkem zkvalitnění počátečního vzdělávání, ale i v důsledku rozšsiření celoživotního vzdělávání. Zásadním problémem současné společnosti se tedy podle autora jeví školská reforma, nikoli reforma důchodová, která je tak často prezentována $\mathrm{v}$ našich médiích. Cílem důchodové reformy je získat prostředky na financování důchodů, avšak vzdělanost si žádném administrativním opatření neopatř́me. Lidé a jejich znalosti, schopnosti a dovednosti, nápady, angažovanost a iniciativa jsou nejcennějším bohatstvím, které společnost má a předpokladem rozvoje, což si zaslouží mimořádnou pozornost.

\section{Literatura}

[1] BECKER, G., S. Human Capital: A Theoretical and Empirical Analysis, with Special Reference to Education. Third Edition, Chicago : The University of Chicago Press, 1993, 390 s., ISBN 0226-04120-4

[2] Český statistický úřad [online]. [2013-04-26]. Dostupné z: $<\mathrm{http}: / / \mathrm{vdb} . c z s o . c z /$ sldbvo/\#! stranka=>

[3] HOLMAN, R. Dějiny ekonomického myšlení. 3. vydání, Praha : Nakladatelství C. H. Beck, 2005, 539 s., ISBN 80-7179-380-9.

[4] KOSCHIN, F. Kapitoly z ekonomické demografie. Praha : VŠE, 2005. 52 s. ISBN 80-245-09598.

[5] Národní vzdělávací fond. Konkurenčni schopnost České republiky - kvalita lidských zdrojů. [online].

[2013-04-16].

Dostupné $<$ http://www.nvf.cz/assets/docs/a6c3e0fac8b6b269e893d80c23488b77/387-0/konkurencnischopnost-cr-2010-2011-analyza.pdf $>$.

[6] OECD. Analýza vzdělávaci politiky 2001. (Přeloženo z anglického originálu Education Policy Analysis - 2001.), Praha : Ústav pro informace ve vzdělávání, 2002.

[7] OECD. PISA 2009 Results: Learning Trends - Changes in student performance since 2000. Volume V, 2010. [online]. [2013-04-24]. Dostupné z: $<$ http://www.oecd.org/document/60/0,3746,en_32252351_46584327_46609852_1_1_1_1,00.html> podle-tematu\&tu $=30712 \& \mathrm{th}=\& \mathrm{v}=\& \mathrm{vo}=$ null $\$$ vseuzem $\overline{\mathrm{i}}=$ null $\&$ void $=>$.

[8] VESELÝ, A. Teorie mnohačetných forem kapitálu. Praha: Univerzita Karlova, 2006, ISSN 1801-5999.

[online].

[2013-04-22].

Dostupné

$\mathrm{Z}$ : $<$ http://publication.fsv.cuni.cz/attachments/117_014_Vesely.pdf $>$. 